\title{
Scatter and obsolescence of journals cited in theses and dissertations of librarianship ${ }^{\text {is }}$
}

\author{
Yaşar Tonta*, Umut Al
}

Department of Information Management, Hacettepe University Faculty of Letters, 06532 Beytepe, Ankara, Turkey

Available online 9 May 2006

\begin{abstract}
This article analyzes the bibliometric features (the number of pages, completion years, the fields of subject, the number of citations, and their distribution by types of sources and years) of 100 theses and dissertations completed at the Department of Librarianship of Hacettepe University between 1974 and 2002. Almost a quarter (24\%) of all dissertations were on university libraries, followed by public libraries (9\%). Doctoral dissertations were, on average, twice as long as master's theses and contained 2.5 times more citations. Monographs received more citations (50\%) than journal articles did (42\%). Recently completed theses and dissertations contained more citations to electronic publications. Fourteen (or 3.2\% of all) journal titles (including Türk Kütüphaneciliği, College \& Research Libraries, and Journal of the American Society for Information Science) received almost half (48.9\%) of all citations. Eighty percent of journal titles were cited infrequently. No correlation was found between the frequency of citations of the most frequently cited journals and their impact factors. Cited journal titles in master's and doctoral theses and dissertations overlapped significantly. Similarly, journal titles cited in dissertations also overlapped significantly with those that were cited in the journal articles published in the professional literature. The distribution of citations to foreign journal titles fit Bradford's Law of Scattering. The mean half-life of all cited sources was 9 years. Sources cited in master's dissertations were relatively more current. Single authorship was the norm in cited resources. Coupled with in-library use data, findings of the present study can be used to identify the core journal titles in librarianship as well as to evaluate the existing library collections to decide which journal titles to keep, discard, or relegate to off-site storage areas.
\end{abstract}

(C) 2006 Elsevier Inc. All rights reserved.

\footnotetext{
is The preliminary findings of the current study appeared (in Turkish) in Al and Tonta (2004).

* Corresponding author. Fax: +90 3122992014.

E-mail addresses: tonta@hacettepe.edu.tr (Y. Tonta), umutal@hacettepe.edu.tr (U. Al).
} 


\section{Introduction}

The description of the source of an idea or the concept of "citation" was developed after the Renaissance, and the first use of footnotes similar to citations goes well back to the 16th century (White, 1985). The main function of a citation is to establish a relationship between the citing and cited documents. Citations can be used to evaluate the relevant sources, support the validity of an author's statements, and provide a more extensive reading list for the initiated researchers (Smith, 1981, pp. 84-85; White, 1985, pp. 38-39).

Citation indexing was first used in 1873 when Shepherd's Citations was published. In the mid-1950s, Eugene Garfield, the founder of the Institute for Scientific Information (ISI), had noticed the importance of citation indexes in studying literature growth and the use, organization, and management of the most frequently cited sources. ISI publishes Science Citation Index, Social Science Citation Index, and Arts and Humanities Citation Index since the early 1960s.

Many researchers have used citation analysis to study the scatter and obsolescence of the literature in a given subject, the productivity of authors, and to determine the most frequently used sources in library collections. Cited sources in both journal articles and dissertations have been studied in the past (Garfield, 1980; Gooden, 2001; Kushkowski, Parsons, \& Wiese, 2003; Kuyper-Rushing, 1999; LaBorie \& Halperin, 1976; Line, 1970; Meadows, 1967; Rousseau, 1987; Smith, 1981; Waugh \& Ruppel, 2004; Zipp, 1996). Formulated in 1934, Bradford's Law of Scattering "describes how the literature on a particular subject is scattered or distributed in the journals" (Garfield, 1980, p. 5). The law states that "if scientific journals are arranged in order of decreasing productivity of articles on a given subject, they may be divided into a nucleus of periodicals more particularly devoted to the subject and several groups or zones containing the same number of articles as the nucleus (Bradford, 1934; as cited in Hertzel, 1987, p. 175). It was observed that the vast majority of articles on a particular subject is published in a relatively small number of "core" journals. In other words, journals can be ranked according to the law of diminishing returns. Trueswell (1969) drew attention to the same phenomenon when he showed that about $80 \%$ of the books circulated in a library accounted for $20 \%$ of the collection (the so-called "80/20 Rule"). Moreover, it was also observed that the current literature gets cited more often in articles published in scientific journals (Earle \& Vickery, 1969; Meadows, 1967), although older literature also gets cited in some disciplines such as the history of medicine. As the literature ages, it receives fewer and fewer citations. This phenomenon is known as "aging" or "obsolescence." The measure of "half-life, defined as the median age of cited or requested sources," has been used to study the obsolescence of literature (Earle \& Vickery, 1969, p. 132; Line, 1970, p. 6).

Theses and dissertations reflect the scholarly communication process. Bibliometric and citation characteristics of dissertations (e.g., the subject fields of dissertations, the number of citations and their distribution by types of sources, years, country of publication, and by number of authors) have been studied in the past with a view to identify the basic features of the scholarly communication process in different fields of study. The scatter and obsolescence of cited sources that appear in the bibliographies of dissertations have been used not only to help identify core journal titles in specific subject fields but also to develop theories that can 
be used in collection management decisions and scientometric evaluations. As the act of citing sources is an indication of their use, the decisions of collection managers as to which journal titles to maintain in the collection or deselect for disposal can be based, at least in part, on citation statistics. Similarly, the rates of obsolescence of journals in certain fields can be used to decide if those journals should be licensed retrospectively through individual or consortial agreements with publishers. Deans of schools could use information on cited journals and their characteristics (e.g., impact factors) to evaluate the types and quality of the sources used in students' studies.

\section{Problem statement}

Bibliometric and citation analyses in librarianship are scarce. Studies on the applicability of the Bradford Law, the 80/20 Rule, and obsolescence to citations appearing in theses and dissertations of librarianship are even scarcer. It would be worthwhile to study if scattering and aging of literature apply equally well to librarianship, along with its implications for collection management in libraries.

The broader research question addressed in this study is as follows: To what extent can bibliometric and scientometric characteristics of dissertations in librarianship be used to formulate collection management policies in libraries? More specifically, this article addresses the following research questions:

- What types of sources (e.g., monographs and journal articles) get cited more often in librarianship?

- What are the most frequently cited journals in librarianship?

- Is there a relationship between the impact factors of journals and the number of citations they get?

- Does the distribution of citations to journals fit Bradford's Law of Scattering?

- Do citation trends in master's and doctoral dissertations differ?

- To what extent do citation trends in theses and dissertations differ from that in professional journal literature?

- What is the rate of literature obsolescence in librarianship?

- Do cited sources in master's and doctoral dissertations differ in terms of their ages?

In order to address these questions, the master's and doctoral dissertations completed at a department of librarianship were selected. Findings to be obtained in such a study could help identify the most heavily cited journal titles in librarianship. Citations represent a certain type of use of journal collections including the usage of backruns of journals. Most heavily cited journal titles can therefore be used, to some extent, to formulate collection management, retention, deselection, relegation, and disposal policies.

Findings presented in this study can be regarded as a case study. Similar citation analyses of theses and dissertations completed at other library schools may reveal if the findings presented here are valid and generalizable. Nevertheless, the case study presents detailed 
findings on how students cite journals and other sources in their theses and dissertations and compares them with the findings of similar studies to reach tentative conclusions with regards to citation analysis in librarianship and its possible use for collection management purposes. Such conclusions can be used to formulate additional research questions in future studies.

\section{Literature review}

The citation analysis was reported in 1927 by Gross and Gross who studied the cited sources in the bibliographies of articles published in the Journal of the American Chemical Society and used the results to develop a journal subscription policy for a college library in the United States (White, 1985, p. 39).

Similarly, bibliometric features of cited sources (e.g., types, years, and countries of publication) in theses and dissertations have also been studied (e.g., Buttlar, 1999; Edwards, 1999; Gooden, 2001; Herubel, 1991; Kushkowski et al., 2003; Kuyper-Rushing, 1999; LaBorie \& Halperin, 1976; Sylvia \& Lesher, 1995; Walcott, 1991, 1994; Zipp, 1996). An analysis of the cited sources in 61 dissertations of library and information science showed that the College \& Research Libraries and Journal of the American Society for Information Science were among the most frequently cited journals (Buttlar, 1999). Monographs were cited more often than journal articles in dissertations in librarianship as well as in music and philosophy (Herubel, 1991, p. 67; Kuyper-Rushing, 1999, p. 160; LaBorie \& Halperin, 1976, pp. 274-278). This pattern was also observed in some other social science disciplines (e.g., political science, psychology, and sociology) (Kushkowski et al., 2003, p. 472). This is in contrast with citation patterns observed in dissertations of chemistry, geology, and biology wherein more than $80 \%$ of all citations were for journal articles (Gooden, 2001; Walcott, 1991, p. 9; Walcott, 1994, p. 4). Journal articles received $64 \%$ of all citations in a crossdisciplinary study of citations taken from master's and doctoral dissertations completed at Iowa State University between 1973 and 1992, and some $85 \%$ of the cited sources were available in the university library (Kushkowski et al., 2003, pp. 465-467). Almost half the cited sources were 20years old or younger in librarianship (LaBorie \& Halperin, 1976, pp. 274-280).

Waugh and Ruppel (2004) reviewed the literature in detail with regards to the use of citation analysis to determine the core journals in various fields (e.g., psychology, women's studies, and workforce education) and referred to studies that identified positive correlations between the journal titles cited most often in theses and dissertations of graduate students and that in faculty publications (e.g., McCain \& Bobick, 1981; Zipp, 1996). They also introduced a weighting formula that not only takes into account the total number of times each journal title is cited but also the percentage of dissertations in which it is cited (p. 280). In other words, a journal title that is cited most often by the greatest number of dissertations gets ranked higher in the list (Waugh \& Ruppel, 2004, p. 280).

Bibliometric studies have been published recently in Turkey too, although citation analyses are rare (Al \& Tonta, 2004; Denkel, Kâğıtçıbaşı, Pak, \& Pamuk, 1999; Tonta, 2000; Tonta \& İlhan, 1997, 2002; Yurtsever \& Gülgöz, 1999; Yurtsever, Gülgöz, Yedekçioğlu, \& Tonta, 
2001, 2002). Kum (1974) selected a random sample of citations from articles published in 30 medical journals from the 1950s through the 1970s and prepared a list of the most frequently cited journals. Although there was a high degree (89\%) of overlap between the titles in the journal subscription list of Hacettepe University Medical Library and that of Sengupta (1974), only $57 \%$ of the back issues of the cited journals were available in the library (Kum, 1974, pp. 49-50). Journals with high impact factors (IFs) were also studied with regards to their availability in the collections of university libraries in Ankara (Alkan, 1998, 1999).

A general study of bibliometric features of contributions (articles, reviews, letters, etc.) authored by Turkish social scientists identified 29 contributions that appeared in 12 different journals of library and information science (LIS) (Gülgöz, Yedekçioğlu, \& Yurtsever, 2002; Yurtsever et al., 2001). The average citations per article was 2.15, and the average number of authors per contribution was 1.3. The impact factors of LIS journals in which Turkish contributions appeared were relatively higher than those of other social science disciplines. This may partly be due to the fact that LIS journals in general have higher IFs. Moreover, whereas journals in psychology usually have high IFs, many contributions of Turkish psychologists appeared in the Turkish Journal of Psychology, a journal with a considerably low impact factor.

Citation analysis studies in librarianship concentrated on the cited sources in articles appearing in the journal Türk Kütüphaneciliği (Journal of Turkish Librarianship) (Gürdal, 2002; Kurbanoğlu, 1996; Tonta, 2002). It appears that monographs were cited more often than journal articles and that the most frequently cited five journals [Türk Kütüphaneciliği, Resmî Gazete (Official Gazette), College \& Research Libraries, Library Trends, Library Journal] received about one third of all citations. Similar findings were obtained for the cited sources in doctoral dissertations (Bayram, 1998; Gökkurt, 1997a, 1997b). The most frequently cited five journals (Türk Kütüphaneciliği, College \& Research Libraries, Library Trends, Journal of the American Society for Information Science and Information Processing \& Management) in 17 dissertations contained 42\% of all citations (Gökkurt, 1997b, p. 159).

This paper aims to study if the Bradford Law fits the distribution and obsolescence of articles appearing in the bibliographies of theses and dissertations in librarianship and corroborates the findings with those of similar studies.

\section{Method}

In order to address the research questions, a total of 100 theses and dissertations (78 master's and 22 doctoral) completed between 1974 and 2002 at the Department of Librarianship of Hacettepe University in Ankara, Turkey, were used as data sources. The department has awarded the highest number of master's and doctoral degrees in Turkey from its establishment in 1972 until it was recently renamed as the Department of Information Management. In addition, the full texts of theses and dissertations used as data sources have already been scanned earlier as part of a project and were thus available online to the authors, thereby facilitating the data gathering and analysis process.

Bibliographies or reference lists of theses and dissertations were used to identify the cited sources. Sources cited were categorized as "monographs" (e.g., books, proceedings, and 
technical reports), "journals" (e.g., scholarly, scientific, and popular journals and magazines, and newspapers ${ }^{1}$ ), "electronic publications" (e.g., articles available through databases or Web sites), "dissertations" (master's, doctoral, and post-doctoral dissertations), and "other publications" (e.g., unpublished manuscripts, interviews, and archival documents). The classification scheme is based on an earlier study (Tonta, 2002) and was meant to be used for comparative purposes. The journal title, language, publication year, and author(s) of each cited source were recorded. The relationships between the most frequently cited journals in master's and doctoral theses and dissertations and between those in dissertations and the professional journal literature were tested using Spearman's rank order correlation coefficient $(\rho)$. Similarly, the relationship between the impact factors of cited journals as reported in ISI's Journal Citation Reports (ISI, 2002) and the number of citations they received in dissertations was tested using Pearson's correlation coefficient $(r)$. In order to find the half-life of cited sources (e.g., books, journals, and other types of publications) for each dissertation, the publication year of each cited source was subtracted from that of the dissertation and the median (i.e., half-life) of cited sources was found. The mean half-life of cited sources was calculated by taking the average of medians for all dissertations. The distribution and obsolescence of articles in cited journals in librarianship was studied to determine if they fit Bradford's Law of Scattering. Authorship was also studied with regards to the nationality of the first author of each cited journal article.

\section{Findings}

On the average, 3.4 dissertations were completed each year at the department, although this figure fluctuates between zero and 10 (no dissertation was completed in 1981 whereas there were 10 in 1978). Considering that the department accepts about 10 graduate students every year, it appears that only one third of accepted students completed the program.

An average dissertation was 171 pages long $(\mathrm{SD}=78, \min =45, \max =450$ ). (It was assumed that such features as the page size, line spacing and font size used in dissertations remained the same from 1974 through 2002.) Doctoral dissertations were twice as long as master's dissertations ( 275 pages as opposed to 142 pages). As the length of a dissertation increases, so does the number of cited sources.

Two professors (N. Tuncer and İ. Çakın) supervised almost half (48\%) of all dissertations whereas 13 others supervised the rest. The number of professors with a $\mathrm{PhD}$ who could act as advisers were limited in the early years. Therefore, an adjunct professor (O. Ersoy) who was with the Department of Librarianship of Ankara University acted as an additional adviser. The scarcity of supervisors may have affected the range of research topics addressed in dissertations as well as the citations therein.

Graduate students explored a wide range of subjects in their theses and dissertations, although university libraries (24\%) and public libraries (9\%) were among the most frequently

\footnotetext{
${ }^{1}$ The Resmî Gazete (the official gazette or newspaper of the Turkish government), the second most frequently cited source in theses and dissertations, was classified under "journals."
} 


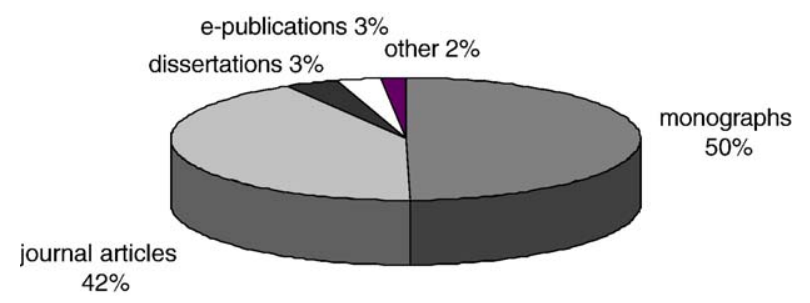

Fig. 1. Distribution of citations by publication type $(N=7019)$.

studied topics, followed by user studies, children's books and school libraries. No pattern was observed in the distribution of topics of the dissertations completed in different time periods.

Dissertations contained a total of 7019 citations (average $=70, \mathrm{SD}=58$ ). The average number of citations in a doctoral dissertation (132) was 2.5 times higher than that of a master's dissertation (53). Monographs received half of all citations (7019), whereas journals received $42 \%$, dissertations and electronic publications $3 \%$ each, and "other publications" $2 \%$ (see Fig. 1). The percentage of citations to electronic publications in dissertations that were completed within the last 4 years was as high as $15 \%$. The percentage of citations to monographs was higher in master's dissertations (52\%) than that of doctoral dissertations (47\%). The subject or the completion year of a dissertation did not seem to be a factor in the distribution of citations by publication types, although the journal titles cited were obviously different.

More than half (55\%) of all cited sources were in English. The rest were mainly in Turkish. Monographs and journal articles in English received more citations (52\%) than those in Turkish (42\%), which can be attributed to the fact that Turkish literature in librarianship is limited. Some $45 \%$ of all citations to articles in Turkish were to the journal Türk Kütüphaneciliği.

Fig. 2 gives the distribution of citations to journal titles. One percent of all journal titles (or five journal titles) received one third of all citations whereas $3.4 \%$ (or 15 journal titles)

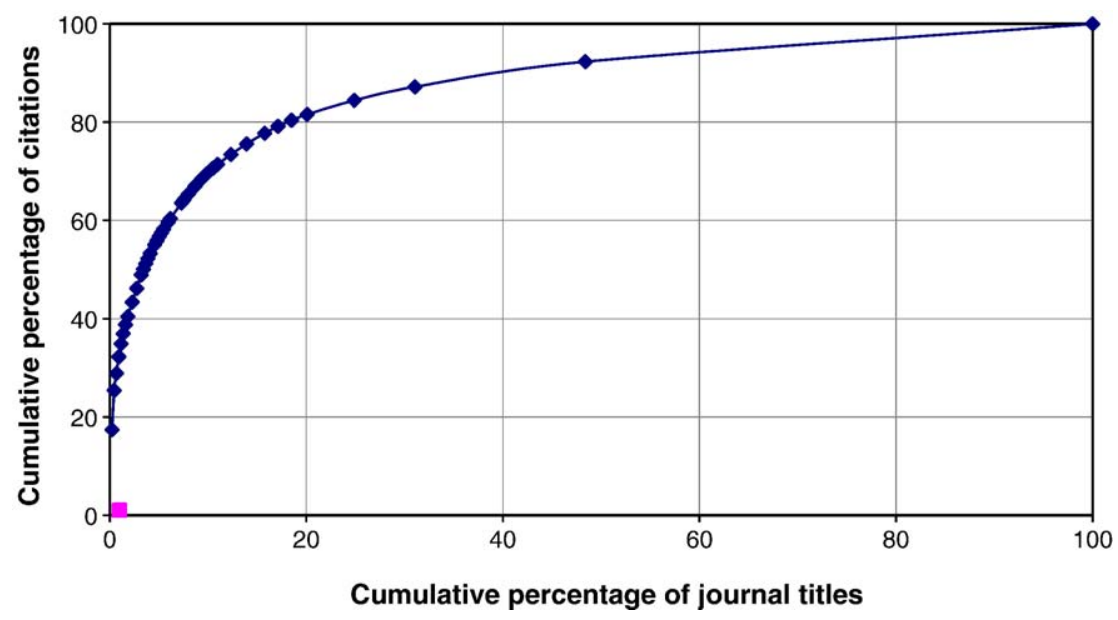

Fig. 2. Distribution of citations to journal titles. 
Table 1

Distribution of citations to journal titles

\begin{tabular}{|c|c|c|c|c|}
\hline \multirow[t]{2}{*}{ Region } & \multicolumn{2}{|c|}{ No. of journal titles } & \multicolumn{2}{|c|}{ No. of citations } \\
\hline & $N$ & $\%$ & $N$ & $\%$ \\
\hline 1 & 4 & 0.9 & 949 & 32.2 \\
\hline 2 & 34 & 7.8 & 1023 & 34.7 \\
\hline 3 & 400 & 91.3 & 973 & 33.0 \\
\hline Total & 438 & 100.0 & 2945 & 99.9 \\
\hline
\end{tabular}

The total percentage of all citations is not equal to $100 \%$ due to rounding.

received half and about $9 \%$ (or 38 journal titles) received two thirds of all citations. More than $80 \%$ of all journal titles were hardly cited.

A test was carried out to find out if the Bradford Law applies to the distribution of citations over journal titles. The total number of journal titles (438) was divided into approximately three equal regions on the basis of the number of total citations that journal titles received in each region (about one third of all citations). Table 1 gives the number and percentages of journal titles along with those of citations for each region. The first one third of all citations went to the most heavily cited four journal titles in the first region whereas the second one third went to 34 moderately cited journal titles. The last one third of all citations went to 400 infrequently cited journal titles. In other words, 38 highly and moderately cited journal titles (a mere $8.7 \%$ of all journal titles) satisfied two thirds of all citations.

The distribution of all citations (2945) over 438 different journals (139 in Turkish, 299 in foreign, mainly English, languages) is given in Fig. 3, which appears to be a typical S-shaped Bradford-Zipf distribution. The graph increases nonlinearly for the most heavily cited top 14 journals. These top 14 journals constituted only $3.2 \%$ of all cited journals (438) yet they received almost half $(48.9 \%)$ of all citations. The sharp increase observed up to the top 14 journals slows down gradually. The top 41 journals $(9.4 \%$ of all titles) received more than two

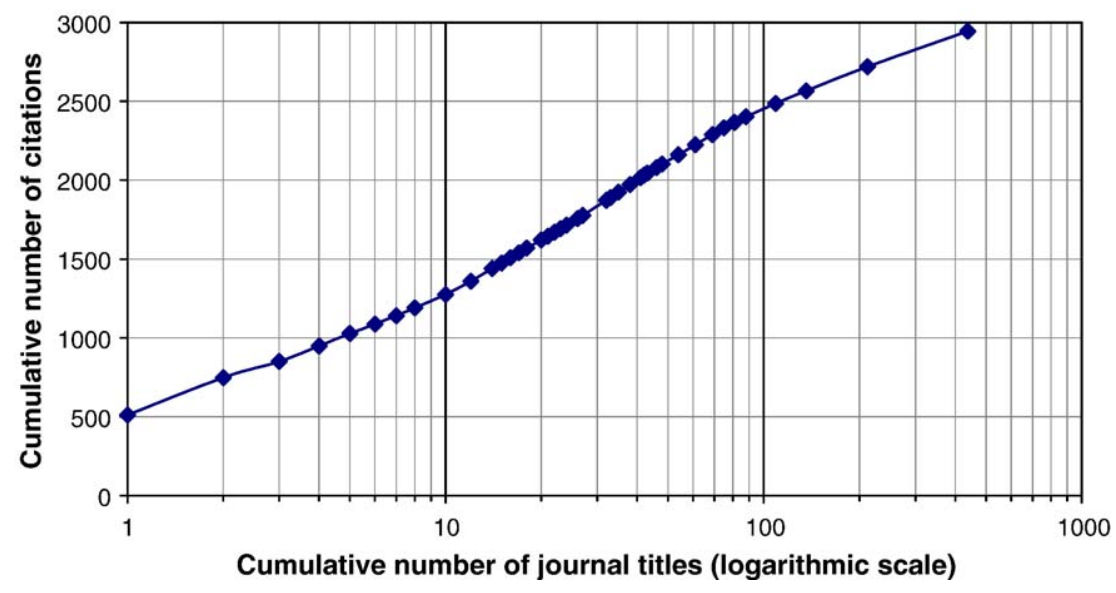

Fig. 3. Distribution of citations to journal titles. 
thirds $(68.5 \%)$ of all citations. Furthermore, some 88 journal titles received more than $80 \%$ of all citations. The increase slows down further after 88 titles. The remaining 350 journal titles (almost $80 \%$ of all cited journals) received only $18.4 \%$ of all citations. Almost half (226) of all cited journals received only one citation each ( $8 \%$ of all citations).

Although Table 1 and the S-shaped distribution depicted in Fig. 3 seem to suggest the applicability of Bradford's Law of Scattering to the distribution of citations over all journal titles, this was not the case. Nevertheless, the distribution of citations to foreign journals fits the law. This may be due to the fact that the two most heavily cited Turkish journals (Türk Kütüphaneciliği and Resmî Gazete) received a quarter of all citations whereas citations to foreign journal titles were less lop sided.

The top 14 journals that received almost half of all citations are given in Table 2. As should be expected, Türk Kütüphaneciliği (Journal of Turkish Librarianship) received the highest number of citations in dissertations (512 citations or about $17 \%$ of all citations to journal articles), followed by Resmî Gazete (236 citations or about $8 \%$ of all citations to journal articles), which is not a professional journal of librarianship per se, but the official gazette of the Turkish government. The remaining journal titles are/were among the prestigious library journals published in English.

The number of journals cited by both master's and doctoral dissertations was 106 (of which 79 were in English and 27 in Turkish). The rank order correlation between the lists of cited journals in master's and doctoral dissertations was statistically significant (Spearman's $\rho=$ $.563, P<.01$ ), suggesting that the overlapping core journal titles were consistently cited both in master's and doctoral dissertations.

All but one of the most frequently cited journals listed in Table 2, and more than half the 54 journals that received 10 or more citations in dissertations were available through the university library whereas 15 journal titles were not.

Table 2

The most heavily cited 14 journals in dissertations

\begin{tabular}{lll}
\hline Journal name & No. of citations & Impact factor $^{\mathbf{a}}$ \\
\hline Türk Kütüphaneciliği (Journal of Turkish Librarianship) & 512 & NA \\
Resmî Gazete (Official Gazette) & 236 & NA \\
College \& Research Libraries & 102 & 1.181 \\
Library Trends & 99 & 0.757 \\
Library Journal & 79 & 0.205 \\
Journal of the American Society for Information Science & 60 & 1.773 \\
UNESCO Bulletin for Libraries (discontinued) & 54 & NA \\
IFLA Journal & 48 & NA \\
Bulletin of the Medical Library Association & 43 & 0.949 \\
International Library Review & 43 & NA \\
Aslib Proceedings & 42 & 0.368 \\
Library Quarterly & 42 & 0.500 \\
Journal of Documentation & 40 & 1.648 \\
Libri & 40 & 0.123 \\
\hline
\end{tabular}

a Source: ISI. Journal Citation Reports (2002). 
The publication years of all cited sources ranged between 1790 and 2002 (see Fig. 4). The mean half-life of sources cited in dissertations was 9 years. Sources cited in master's dissertations were slightly younger than those of doctoral dissertations, suggesting that more current literature is cited in master's dissertations. Sources cited in dissertations on university libraries were slightly more current. The half-life for cited books and journal articles were 9.3 years and 9.6 years, respectively. The half-life for cited journals in foreign languages ( 8 years) was younger than that in Turkish (10 years), whereas the reverse was the case for books. This may be due to the fact that foreign journals provide more up-to-date information and they can be obtained more easily once they are subscribed to by libraries. Yet, foreign books take longer to arrive in Turkish libraries and seem to appear some time later in the bibliographies of dissertations. The overwhelming majority of sources cited in dissertations were published between 1980 and 2002.

The great majority $(86 \%)$ of the cited sources in dissertations had single authors whereas $11 \%$ had two, $2 \%$ had three, and $1 \%$ had four or more. The average number of authors of cited sources was 1.2. Although single authorship is the norm in librarianship as in other social science disciplines, sources with multiple authors seem to be cited more often in dissertations completed in recent years. For instance, one third of all citations to sources with multiple authors (745) came from 13 dissertations (13\% of all dissertations) that were completed between 2000 and 2002. It is likely that the number of sources with multiple authors (and thus citations to such sources) will increase, as supported research projects will proliferate.

The contribution of Turkish researchers to the literature seems to be limited. Sources authored by Turkish researchers received about one third of all citations. A total of 1901 sources that were authored by 787 different Turkish researchers were cited in dissertations. Some 20 sources authored by Turkish researchers received one third of all citations whereas 74 sources received one half of all citations. The contributions of more than 700 Turkish authors received only the remaining one half all citations.

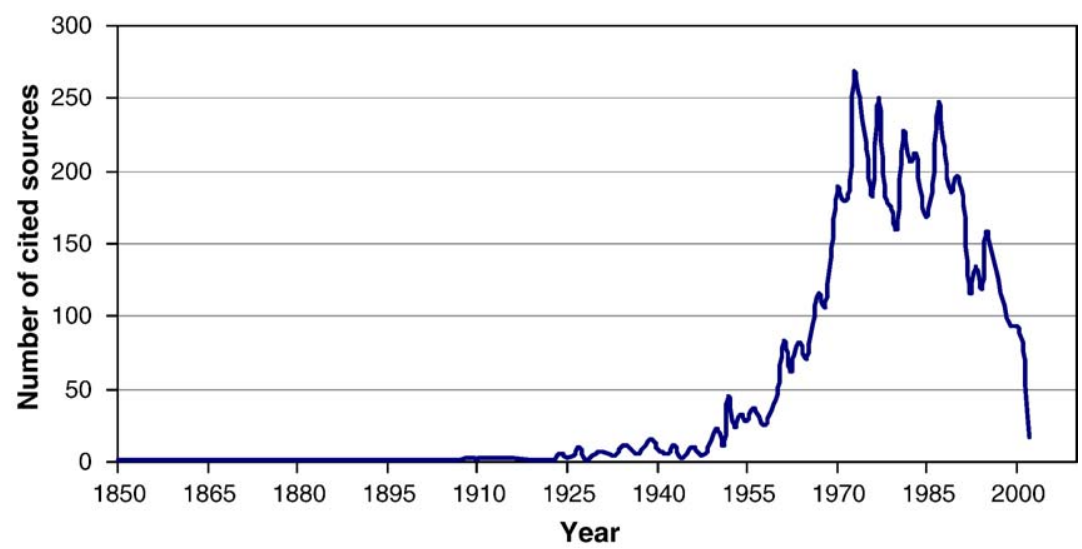

Fig. 4. Distribution of citations by years $(N=7019)$. 


\section{Discussion}

Findings indicate that monographs were cited slightly more often $(50 \%)$ in theses and dissertations of librarianship than journal articles (42\%). Monographs were also cited more heavily (53\%) in journal articles that appeared in Türk Kütüphaneciliği (Journal of Turkish Librarianship) between 1987 and 2001 (Tonta, 2002, p. 282). It appears that the types of sources cited in journal articles and dissertations are similar and that monographs are used more often than journal articles in librarianship, which confirmed the findings of similar studies carried out in the past (LaBorie \& Halperin, 1976, p. 278). Doctoral dissertations contained more citations than master's dissertations because they were twice as long. Sources published within the last 8 years received half of all citations. Cited sources in master's dissertations tend to be more current.

The Türk Kütüphaneciliği (Journal of Turkish Librarianship), Resmî Gazete (Official Gazette), College \& Research Libraries, Library Trends, Library Journal, and Journal of the American Society for Information Science were among the most frequently cited journals in dissertations and these journals received more than one third of all citations. Some $18.5 \%$ (or 81 journal titles) of all journal titles met $80 \%$ of all citation needs, conforming to Trueswell's famous 80/20 rule (Trueswell, 1969). Yet, Bradford's Law of Scattering did not seem to apply well to citations over all journal titles, although citations to foreign journal titles (mostly in English) exhibited a more Bradfordian distribution. This is due in large part to the fact that the top two Turkish journals received a quarter of all citations, thereby skewing the otherwise Bradfordian distribution. Overlapping core journal titles were consistently cited both in master's and doctoral dissertations, and the correlation between them was statistically significant. This finding further reinforces the fact that there is a core journal list in librarianship that is referred to by graduate students as well as by faculty members and researchers. There appears to be no statistically significant correlation between the frequency of citations of the most frequently cited journals and their impact factors.

Distributions similar to that given in Fig. 2 earlier can also be studied using concentration and evenness measures. Rousseau (2000, p. 2) describes concentration as "the relative apportionment of items among the sources present." Lorenz curves and Gini coefficients as concentration measures were originally developed to study income inequality in economics (Jacobson, Milman, \& Kammen, 2004). They are used as scientometric indicators to evaluate the distribution of citations in journal articles over journal titles (Rousseau, 1998, 2000). Jacobson et al. (2004) describe Lorenz curves and Gini coefficients in the context of energy consumption:

\footnotetext{
The Lorenz curve is a ranked distribution of the cumulative percentage of the population of recipients on the abscissa versus the cumulative percentage of the resource distributed along the ordinate axis... . The Gini coefficient is a numeric measure of inequality that reveals the difference between a uniform distribution and the actual distribution of a resource (p. 2).
}

Fig. 5 shows the distribution of citations over journal titles using the Lorenz curve and its associated Gini coefficient (.75). Taken from Jacobson et al. (2004, p. 2), the formula,

$$
G_{e}=1-\Sigma\left(Y_{i+1}+Y_{i}\right)\left(X_{i+1}-X_{i}\right)
$$




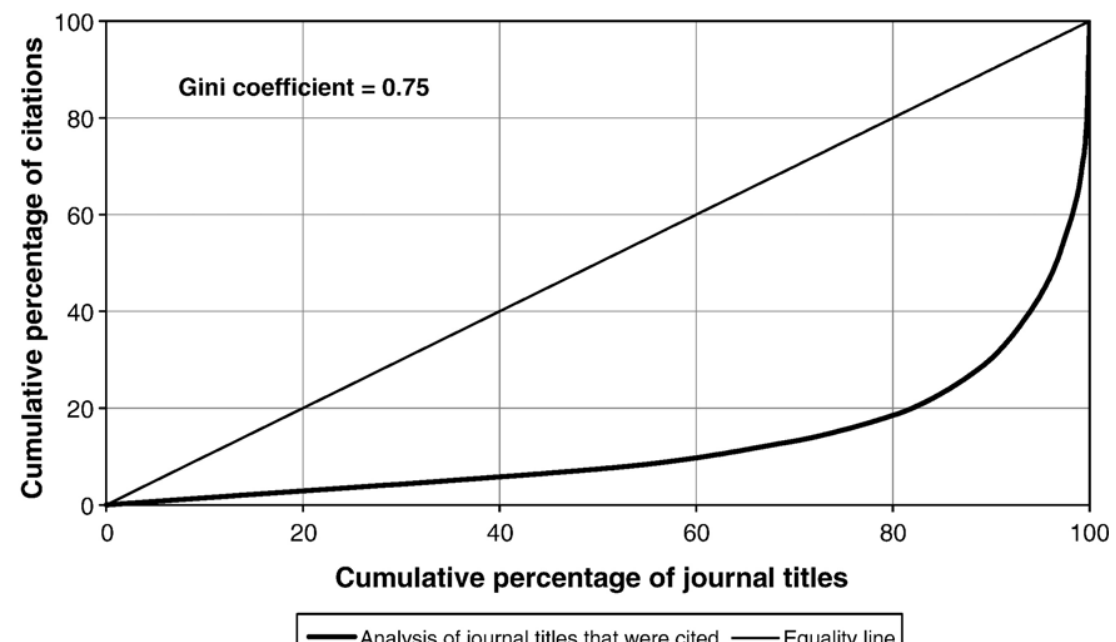

Fig. 5. The Lorenz curve and the Gini coefficient for the distribution of citations over journal titles.

was used to calculate the Gini coefficient where $X_{i}$ in Eq. (1) is the number of journal titles in journal group $i$ /total number of journal titles, and $Y_{i}$ is the number of citations in citation group $i$ /total citations with $Y_{i}$ ordered from lowest to highest number of citations. Figs. 2 and 5 represent the same data in two different ways. Fig. 5 concentrates on the large percentage of journal titles that were cited rather infrequently, whereas Fig. 2 draws attention to a small percentage of "core" journal titles receiving a relatively large percentage of total citations. Fig. 5 brings forth the inequality in the distribution of citations over journal titles, which is further illustrated by the relatively high Gini coefficient of $.75 .^{2}$ The Lorenz curve in Fig. 5 also shows clearly the validity of the $80 / 20$ rule: $80 \%$ of all journal titles received less than $20 \%$ of all citations (Trueswell, 1969).

Fourteen journal titles receiving almost half (48.9\%) of all citations in theses and dissertations can be considered as the "core journals" cited in Turkish dissertations of librarianship because they also appeared among the most frequently cited journals in similar studies (Gökkurt, 1997b; Kurbanoğlu, 1996; Tonta, 2002). For instance, the top 10 journal titles in this study are the same as those reported in Kurbanoğlu (1996) and Tonta (2002). Four out of the six most frequently cited journals in 17 doctoral dissertations studied by Gökkurt (1997b, p. 159) and the present study overlap. The five most frequently cited journals contained $42 \%$ of all citations in Gökkurt's study, whereas this percentage was slightly lower in the present study (35\%). Furthermore, the ranks of cited journals in different studies are also similar. Correlation between the ranks of cited journals in theses and dissertations and those in the journal literature (Tonta, 2002) was statistically significant (Spearman's $\rho=.596, P<.01$ ). These findings tend to reinforce the fact further that there is a core journal list in librarianship that is referred to by graduate students as well

\footnotetext{
2 "The Gini coefficient ranges from perfect equity among all members of the population $\left(G_{e}=0\right)$ to complete inequity $\left(G_{e}=1\right)$ " (Jacobson et al., 2004, p. 2).
} 
as by faculty members and researchers. There is a strong correlation between the ranks of journal titles calculated by the total number of citations they received and by the weighting formula used by Waugh and Ruppel (2004) (Spearman's $\rho=.901, P<.01$ ).

Such journal titles as Information Technology \& Libraries, Library Resources \& Technical Services, Information Processing \& Management, Library \& Information Science Research, Journal of Information Science, and Journal of Academic Librarianship were cited less frequently. Some of these titles (e.g., Library \& Information Science Research) were not available through the university library whereas the great majority of the most frequently cited journals were. This may very well be the reason for low citation rates for those journals.

No statistically significant correlation was observed between the frequency of citations of the most frequently cited journals and their impact factors (Pearson's $r=.197, P=.28$ ), suggesting that the impact factor of a given journal cannot be used as a reliable indicator to predict the frequency of citations it receives in dissertations of librarianship.

The figures of half-lives and the distribution of ages of cited sources in theses and dissertations were similar to those obtained in Turkish journal articles (Tonta, 2002, pp. 307-308). The last 5 years of the journal literature received one third of all citations in our study. This period was found to be 8 years for doctoral dissertations in a separate study (Bayram, 1998, p. 30), which further reinforces the fact that bibliographies of doctoral dissertations contain relatively older citations. Similar studies of obsolescence have also been carried out elsewhere. LaBorie and Halperin (1976, p. 280) found that $24 \%$ of all citations in dissertations were to sources of $0-5$ years of age, $12 \%$ to sources of $6-10$ years of age, $13 \%$ to sources of 11-20years of age, and 51\% to sources of more than 20 years of age. The half-life of about 20 years reported by LaBorie and Halperin is much higher than that in this study (9years). LaBorie and Halperin's study contained more dissertations on historical subjects citing relatively older sources, which was presumably reflected in the obsolescence rate.

The overwhelming majority of the cited sources in dissertations had single authors. The average number of authors of cited sources in dissertations (1.2) is comparable to that in journal articles (1.3) authored by Turkish librarians and published in journals indexed in the Social Science Citation Index (Gülgöz et al., 2002).

\section{Conclusion}

Findings obtained in this study reinforce the findings of previous ones. Journal articles get cited more often than monographs and the percentage of citations to electronic publications is on the rise. There appears to exist a core list of journals in librarianship that consistently get cited most often not only in theses and dissertations but also in the professional literature as well. The distribution of all cited journals did not fit Bradford's Law quite well, although the $80 / 20$ Rule was validated. The most current 5 -year backruns of core journal titles received one third of all citations in theses and dissertations and in the journal articles. The mean half-life of cited articles was 9 years. The overlap among the cited journal titles in different studies was quite high. The overwhelming majority of journal titles were cited rather infrequently. There appears to be no meaningful relationship 
between the number of citations a journal title receives and its impact factor, which seems to suggest that citations in the dissertations may not be a good indicator of the actual usage of the literature in librarianship. Nonetheless, as the act of citing a journal title in dissertations or in professional articles represents implicit use of the library resources, the list of core journal titles that get cited most frequently can be used for collection management purposes. Libraries can subscribe to or license such journal titles and provide access to their current issues and backruns. Journal titles that go uncited or are rarely cited may be ignored for collection development purposes. If the library already maintains such journal titles, they can be marked for deselection. Policies regarding the procurement of articles that appeared in rarely used journals can also be developed.

Findings seem to suggest that there exists a correlation between the number of citations a journal receives and its availability through the university library at the time the dissertation was completed. An in-depth study needs to be carried out to find out if there is a strong correlation between the in-library use and citation statistics of journal titles.

Findings reported in this study with regards to the distribution of citations in theses and dissertations by types of sources, the existence of a list of core journal titles in librarianship, the relationship (or lack thereof) between the impact factors of journals and the number of citations they get, and the rate of literature obsolescence in librarianship are subject to change and need to be further replicated.

\section{References}

Al, U., \& Tonta, Y. (2004). Atıf analizi: Hacettepe Üniversitesi Kütüphanecilik Bölümü tezlerinde atıf yapılan kaynaklar [Citation analysis: Cited sources in dissertations completed at the Department of Library Science, Hacettepe University]. Bilgi Dünyas1, 5, 19-47.

Alkan, N. (1998). Temel ve uygulamalı bilim dallarında etki faktörü değeri en yüksek olan süreli yayınların Ankara'daki üniversite kütüphanelerinde bulunabilirliği [Journals with the highest impact factors in pure and applied sciences and their availability in university libraries in Ankara]. Türk Kütüphaneciliği, 12, 279-305.

Alkan, N. (1999). Tıp ve sağlık bilimleri dallarının 1990'larda etki faktörü değeri en yüksek olan süreli yayınları ve bunların Ankara'daki ilgili kütüphanelerde bulunabilirliği [Journals with the highest impact factors in medical and health sciences in 1990s and their availability in libraries in Ankara]. Bilginin Serüveni: Dünü, bugünü ve yarın1... [Adventure of information: Its past, present and future...] (pp. 278-300). Ankara: Türk Kütüphaneciler Derneği.

Bayram, Ö. (Gökkurt) (1998). Atıf verisi (citation data) ve enformetrik yasalar: Türk kütüphanecilik literatüründeki doktora tezleri üzerinde bir uygulama [Citation data and informetrics laws: An application to doctoral theses in Turkish librarianship]. Türk Kütüphaneciliği, 12, 21-32.

Bradford, S. C. (1934). Sources of information on specific subjects. Engineering, 137, 85-86.

Buttlar, L. (1999). Information sources in library and information science doctoral research. Library \& Information Science Research, 21, 227-245.

Denkel, A., Kâğıtçıbașı, Ç., Pak, N. K., \& Pamuk, Ş. (1999). Türkiye'de sosyal bilimlerin uluslararası yayın performansı [International publication performance of Turkey in social sciences]. Ankara: Türkiye Bilimler Akademisi.

Earle, P., \& Vickery, B. (1969). Social science literature use in the UK as indicated by citations. Journal of Documentation, 25, 123-141. 
Edwards, S. (1999). Citation analysis as a collection development tool: A bibliometric study of polymer science theses and dissertations. Serials Review, 25, 11-20.

Garfield, E. (1980). Bradford's Law and related statistical patterns. Current Contents, 19, 5-12. Retrieved January 10, 2004 from http://www.garfield.library.upenn.edu/essays/v4p476y1979-80.pdf

Gooden, A. M. (2001). Citation analysis of chemistry doctoral dissertations: An Ohio State University case study. Issues in Science \& Technology Librarianship, 32. Retrieved January 10, 2004 from http://www.istl.org/istl/ 01-fall/refereed.html

Gökkurt, Ö. (1997a). "Citation” indeks ve 'citation' analizi: Enformetrik bir model çalışması [Citation index and citation analysis: A study of an informetric model]. Unpublished $\mathrm{PhD}$ dissertation. Ankara University, Ankara.

Gökkurt, Ö. (1997b). Yoğunlaşma teorisi ve atıf analizinde kullanımı [Concentration theory and its use in citation analysis]. Kütüphanecilik Bölümü 25. Yıla Armağan [A festschrift to honor the 25th anniversary of the foundation of the Department of Librarianship, Hacettepe University] (pp. 153-161). Ankara: Hacettepe University.

Gülgöz, S., Yedekçioğlu, Ö. A., \& Yurtsever, E. (2002). Turkey's output in social science publications: 1970-1999. Scientometrics, 55, 103-121.

Gürdal, O. (2002). Altın y1lını yaşayan Türk Kütüphaneciliği dergisinden yansımalar [Reflections from the Journal of Turkish Librarianship in its golden year]. Türk Kütüphaneciliği, 16, 321-328.

Hertzel, D. H. (1987). Bibliometrics, history of the development of ideas in. In A. Kent (Ed.), Encyclopedia of library and information science, vol. 42 (pp. 144-219). New York: Marcel Dekker.

Herubel, J.-P. V. M. (1991). Philosophy dissertation bibliographies and citations in serials evaluation. Serials Librarian, 20, 65-73.

ISI. (2002). Institute for Scientific Information. Journal Citation Reports. Retrieved September 21, 2003 from http://jcrweb.com

Jacobson, A., Milman, A. D., \& Kammen, D. M. (2004). Letting the (energy) Gini out of the bottle: Lorenz curves of cumulative electricity consumption and Gini coefficients as metrics of energy distribution and equity. Energy Policy. Retrieved November 20, 2004 from http://www.sciencedirect.com.

Kum, İ. (1974). Türkiye'de tıp kütüphaneleri [Medical libraries in Turkey]. Unpublished associate professorship dissertation. Hacettepe University, Ankara.

Kurbanoğlu, S. S. (1996). Türk kütüphanecilerinin kullandığı dergiler [Journals cited by Turkish librarians]. Türk Kütüphaneciliği, 10, 105-118.

Kushkowski, J. D., Parsons, K. A., \& Wiese, W. H. (2003). Master's and doctoral thesis citations: Analysis and trends of a longitudinal study. Portal: Libraries and the Academy, 3, 459-479. Retrieved September 22, 2003 from http://muse.jhu.edu/journals/portal_libraries_and_the_academy/v003/3.3kushkowski.pdf

Kuyper-Rushing, L. (1999). Identifying uniform core journal titles for music libraries: A dissertation citation study. College \& Research Libraries, 60, 153-163.

LaBorie, T., \& Halperin, M. (1976). Citation patterns in library science dissertations. Journal of Education for Librarianship, 14, 271-283.

Line, M. B. (1970). The 'half-life' of periodical literature: Apparent and real obsolescence. Journal of Documentation, 26, 46-54.

McCain, K. W., \& Bobick, J. E. (1981). Patterns of journal use in a departmental library: A citation analysis. Journal of the American Society for Information Science, 32, 257-267.

Meadows, A. J. (1967). The citation characteristics of astronomical research literature. Journal of Documentation, $23,28-33$.

Rousseau, R. (1987, August, 25-28). Citation distribution of pure mathematics journals. In L. Egghe, \& R. Rousseau (Eds.), Informetrics 87/88: Select Proceedings of the First International Conference on Bibliometrics and Theoretical Aspects of Information Retrieval, Diepenbeek, Belgium (pp. 249-262). Amsterdam: Elsevier.

Rousseau, R. (1998). Evenness as a descriptive parameter for department or faculty evaluation studies. In E. De Smet (Ed.), Informatiewetenschap 1998 (pp. 135-145). Antwerp: Werkgemeenschap Informatiewetenschap. http://users.pandora.be/ronald.rousseau/Even_conf.pdf

Rousseau, R. (2000, October 23-25). Concentration and evenness measures as macro-level scientometric 
indicators. Paper presented at the Second International Seminar on Quantitative Evaluation of Research Performance-Shanghai. Retrieved November 19, 2004 from http://users.pandora.be/ronald.rousseau/ Rousseau_Shanghai_2000.pdf

Sengupta, I. N. (1974). Impact of scientific periodicals on the advancement of medical knowledge: An objective method of analysis. International Library Review, 4, 169-195.

Smith, L. C. (1981). Citation analysis. Library Trends, 30, 83-106.

Sylvia, M., \& Lesher, M. (1995). What journals do psychology graduate students need? A citation analysis of thesis references. College \& Research Libraries, 56, 313-318.

Tonta, Y. (2000). Contribution of Turkish researchers to the world's biomedical literature (1988-1997). Scientometrics, 48, 71-84.

Tonta, Y. (2002). Türk Kütüphaneciliği dergisi, 1987-2001 [The Journal of Turkish Librarianship, 1987-2001]. Türk Kütüphaneciliği, 16, 282-320.

Tonta, Y., \& İlhan, M. (1997). Sosyal bilimlerde Türkiye'nin dünyadaki yeri [Turkey's place in social sciences in the world]. Türk Psikoloji Dergisi, 12, 67-74.

Tonta, Y., \& İlhan, M. (2002). Contribution of Hacettepe University Faculty of Medicine to the world's biomedical literature (1988-1997). Scientometrics, 55, 123-136.

Trueswell, R. L. (1969). Some behavioral patterns of library users: The 80/20 rule. Wilson Library Bulletin, 43, $458-461$.

Walcott, R. (1991). Characteristics of citations in geoscience doctoral dissertations accepted at United States academic institutions 1981-1985. Science \& Technology Libraries, 12(2), 5-16.

Walcott, R. (1994). Local citation studies: A shortcut to local knowledge. Science \& Technology Libraries, 14(3), $1-14$.

Waugh, C. K., \& Ruppel, M. (2004). Citation analysis of dissertation, thesis, and research paper references in workforce education and development. Journal of Academic Librarianship, 30, 276-284.

White, E. C. (1985, Winter). Bibliometrics: From curiosity to convention. Special Libraries, 76, 35-42.

Yurtsever, E., \& Gülgöz, S. (1999). The increase in the rate of publications originating from Turkey. Scientometrics, 46, 321-336.

Yurtsever, E., Gülgöz, S., Yedekçioğlu, Ö. A., \& Tonta, M. (2001). Sosyal Bilimler Attf Dizini'nde (SSCI) Türkiye: 1970-1999 [Turkey in the Social Science Citation Index; 1970-1999]. Ankara: Türkiye Bilimler Akademisi.

Yurtsever, E., Gülgöz, S., Yedekçioğlu, Ö. A., \& Tonta, M. (2002). Sağlık bilimleri, mühendislik ve temel bilimlerde Türkiye'nin uluslararası at1 dizinindeki yeri: 1973-1999 [Turkey's place at international citation index in medical sciences, engineering and pure sciences; 1973-1999]. Ankara: Türkiye Bilimler Akademisi.

Zipp, L. S. (1996). Thesis and dissertation citations as indicators of faculty research use of university library journal collections. Library Resources \& Technical Services, 40, 335-342. 